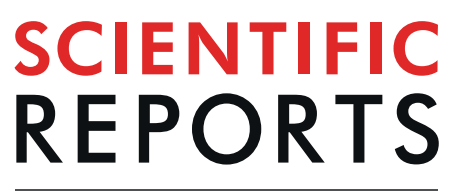

natureresearch

\title{
OPEN Author Correction: The Effect of Electronic Cigarette User Modifications and E-liquid Adulteration on the Particle Size
Profile of an Aerosolized Product
}

\author{
Haley A. Mulder, Jesse L. Patterson, Matthew S. Halquist, Leon Kosmider, \\ Joseph B. McGee Turner D, Justin L. Poklis, Alphonse Poklis \& Michelle R. Peace
}

Correction to: Scientific Reports https://doi.org/10.1038/s41598-019-46387-2, published online 15 July 2019

This Article contains an error in the Acknowledgements section.

“This project was supported by Award No. NIJ-2016-4305, awarded by the National Institute of Justice, Office of Justice Programs, U.S. Department of Justice and the National Institutes of Health Award No. P30DA033934."

should read:

"This project was supported by Award No. 2016-DN-BX-0150, awarded by the National Institute of Justice, Office of Justice Programs, U.S. Department of Justice and the National Institutes of Health Award No. P30DA033934."

(c) (i) Open Access This article is licensed under a Creative Commons Attribution 4.0 International cc) License, which permits use, sharing, adaptation, distribution and reproduction in any medium or format, as long as you give appropriate credit to the original author(s) and the source, provide a link to the Creative Commons license, and indicate if changes were made. The images or other third party material in this article are included in the article's Creative Commons license, unless indicated otherwise in a credit line to the material. If material is not included in the article's Creative Commons license and your intended use is not permitted by statutory regulation or exceeds the permitted use, you will need to obtain permission directly from the copyright holder. To view a copy of this license, visit http://creativecommons.org/licenses/by/4.0/.

(C) The Author(s) 2020 